\title{
Improving the Nutritional Values of Wheat and Rice Crackers by Using Cauliflowers
}

\author{
Dalia M. El Sheikh, Manal S. Helal, Heba A. Barakat \\ Food Technology Research Institute, Agricultural Research Center, Giza, Egypt \\ Email: dr_dalia2@hotmail.com
}

How to cite this paper: El Sheikh, D.M., Helal, M.S. and Barakat, H.A. (2021) Improving the Nutritional Values of Wheat and Rice Crackers by Using Cauliflowers. Food and Nutrition Sciences, 12, 643-658. https://doi.org/10.4236/fns.2021.126048

Received: March 23, 2021

Accepted: June 26, 2021

Published: June 29, 2021

Copyright $\odot 2021$ by author(s) and Scientific Research Publishing Inc. This work is licensed under the Creative Commons Attribution International License (CC BY 4.0).

http://creativecommons.org/licenses/by/4.0/

\begin{abstract}
The present study described the enhancement of the nutritional values of wheat and rice crackers by adding cauliflowers. The results showed that $25 \%$ $75 \%$ cauliflower replaced in crackers increased the consumer acceptability, nutritional value, antioxidant activity, minerals, and anti-carcinogenic effect. Moreover, it also improved the functional properties and sensory quality. The results revealed that the raw samples of cauliflower recorded the highest value of moisture, ash, protein and fiber $89.29 \%, 7.68 \%, 19.04 \%$ and $10.18 \%$ on dry weight, respectively. The crackers formula of cauliflower: wheat 75\%:25\% and cauliflower: rice 75\%:25\% recorded the highest values in ash, protein, fat, and fiber. The data showed that increasing cauliflower percentage in crackers formula causing a parallel increase in all determined chemical composition. Cauliflower samples exhibited the highest antioxidant activity (92.94\%). Also, crackers samples of cauliflower: wheat $75 \%: 25 \%$ crackers, recorded $57.6 \%$ for antioxidant activity. The highest values of phenols and flavonoids for cauliflower cracker samples (cauliflower: wheat 75\%:25\% and cauliflower: rice 75\%:25\%) have increased up to (5.75 and 5.49), (2.70 and 2.54) respectively. The results showed that the higher mineral content is the sulfur (635.96 $\mathrm{mg} / 100 \mathrm{~g})$ in raw cauliflower, while $(1.00 \mathrm{mg} / 100 \mathrm{~g}$, and $0.99 \mathrm{mg} / 100 \mathrm{~g}$ sulfur content) in wheat and rice respectively. Moreover, the result found that as the cauliflower percentage increases, the minerals contents especially sulfur increase. Furthermore, the cauliflower displayed moderate activity for human hepatocellular carcinoma, colon cancer and intestinal epithelial barrier treatment, $\left(\mathrm{IC}_{50}=183.4 \pm 6.8,175.8 \pm 7.1\right.$ and $207.2 \pm 8.5 \mu \mathrm{g} / \mathrm{mL}$, respectively). There were significant differences in the taste property; the highest degree of acceptance of the taste was obtained to crackers samples which were replaced with cauliflower more than the control.
\end{abstract}

\section{Keywords}

Cauliflower, Wheat, Rice, Crackers, Phenols, Flavonoids, Antioxidants, Hepatocellular, Colon intestinal, Glutenfree 


\section{Introduction}

Cauliflower is one of several vegetables in the species Brassica oleracea, the Brassicaceae family is an annual plant that reproduces by seed. Typically, only the head (the white curd) is eaten. The cauliflower head is composed of a white inflorescence meristem. Its commercial cultivation as an off-season vegetable crop for remunerative returns, gives it more demand in the markets of neighboring plains and improved nutritional awareness of people, attracting the farmers to bring large area under its cultivation [1]. Brassica vegetables include some economically interesting crops such as cabbage, broccoli, cauliflower, and turnip, which have consumed the entire world. High consumption of these vegetables was associated with a decreased risk of cardiovascular diseases, cancer and degenerative pathologies [2]. Cauliflower contains several phytochemicals, common in the cabbage family, which may be beneficial to human health. Sulforaphane, a compound released when cauliflower is chopped or chewed, may protect against cancer. A high intake of cauliflower has been associated with reduced risk of aggressive prostate cancer [3]. Consumption of cruciferous vegetables is linked to suppression of many cancers including breast, prostate, lung, and colon cancer [4] [5]. The Organic sulfur compounds derived from plants can serve as chemopreventive and/or chemotherapeutic agents and have been attracting medical and research interest as a promising source for novel anti-cancer agents [6].

Phenolic compound is a generic term that refers to a large number of compounds widely dispersed throughout the plant kingdom. The flavonoids are essential constituents of the cell's plants with high antioxidant activity and important antioxidant ability and involved in a vast diversity of biological functions (anticancer, immunomodulator, and cellular homeostasis) [7] [8]. Cauliflower has higher antioxidant potential which makes it very interesting crop from the consumer's point of view. It is considered a rich source of both antioxidant and anticarcinogenic properties [9].

Celiac disease $(\mathrm{CD})$ is a permanent inflammatory disease of the small intestine triggered by the ingestion of gluten-containing cereals. It is an immune-mediated disorder that affects primarily the gastrointestinal tract. As gluten-free products available in the market are known to have low nutritional quality as well as more expensive than gluten-containing food products, there is a strong need to develop gluten-free products that are nutritionally complete as well as economically [10].

Consumer's demand for healthy snacks is increasing. Therefore, snack crackers can be considered as one of the most required snacks owing to their good eating quality and greater nutritional properties. Moreover, crackers can be utilized as a source of incorporation of different nutritionally rich ingredients for diversification [11].

Therefore, this study was carried out to evaluate the nutritional value, anticarcinogenic of wheat and rice crackers replacement with cauliflower. Also, this work evaluated the ability of caliuflower as new low-priced gluten free and healthy crackers with high-quality characteristics. 


\section{Material and Methods}

\subsection{Materials}

Fresh white cauliflower (Brassica oleracea L. var. botrytis) was obtained from local market in Giza, Cairo, Egypt. Each floret (edible portion), separated, washed, dried and then weighed. The cauliflower samples were crushed by high-speed laboratory blender to obtain finely divided powder. Wheat, rice flour and other ingredients used in crackers were obtained from the local markets.

\section{Preparation of crackers:}

The crackers were prepared according to the method described by [12] with some modification in the formula. The blends and ingredients used for production of crackers were of the tabulated in Table 1 .

For making cracker the following procedure was followed: all ingredients were blended using a laboratory mixer for $4 \mathrm{~min}$ and the resulted dough was left to rest for $15 \mathrm{~min}$., then the dough was removed from the bowel and shaped to the final form and given $40 \mathrm{~min}$ as a fermentation time at $37^{\circ} \mathrm{C}$ and $85 \%$ relative humidity.

To every prepared cracker: 15 gm corn oil, 1 gm dry yeast, 1 gm dry milk, 2 gm salt and $1 \mathrm{gm}$ improver, were added to flour, and water is added as required. The fermented cracker was drilled and painted by egg ( $40 \mathrm{gm}$ whole egg and 0.5 gm anise) for cracker face, then baked at $200^{\circ} \mathrm{C}$ for 6 min. after baking; crackers were allowed to cool at room temperature for $1 \mathrm{hr}$. before organoleptic evaluation.

\subsection{Analytical Methods}

\section{Chemical analyses:}

Chemical composition of flour and crackers samples including moisture, protein, ash, fiber and fat were conducted in Food Technology Research Institute

Table 1. The blends and formula used for preparing crackers.

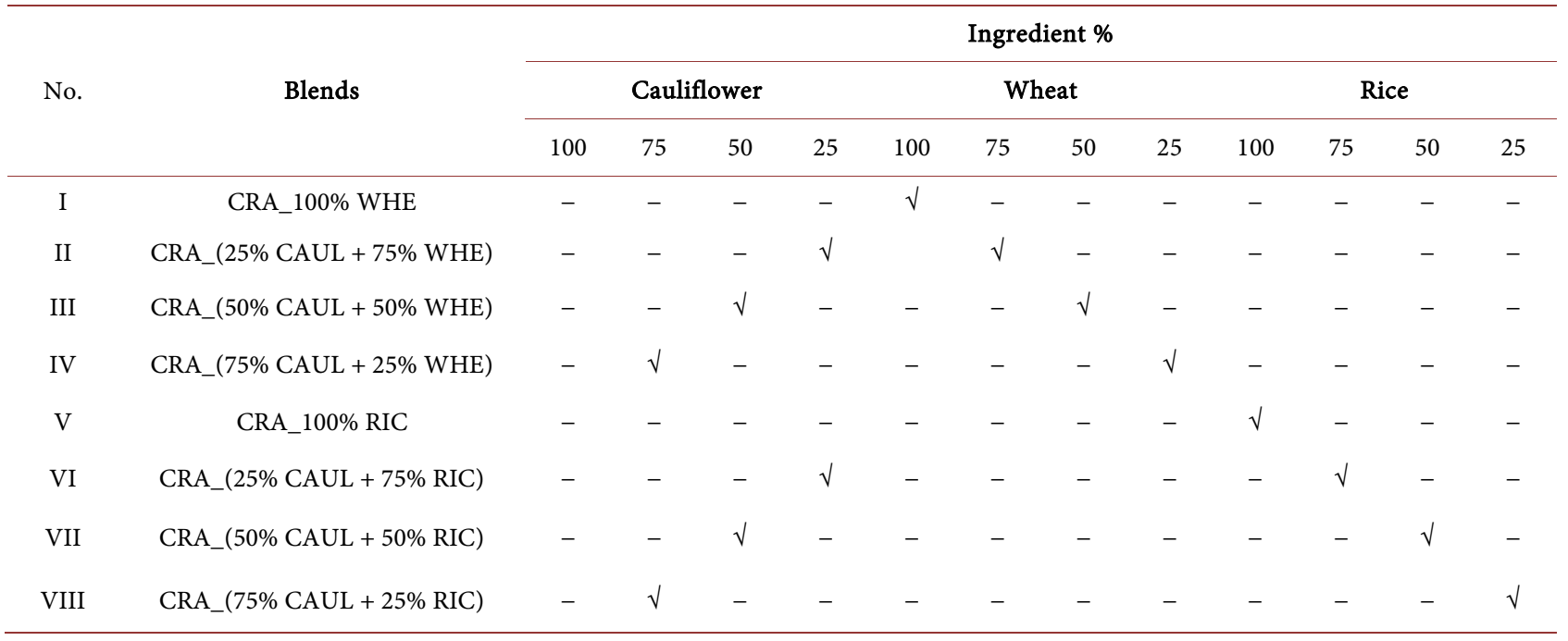

${ }^{\star}$ CRA: Crackers; ${ }^{* *}$ CAUL: Cauliflower; ${ }^{* *}$ WHE: Wheat; ${ }^{* * * *}$ RIC: Rice. 
according to the method described by [13] and carbohydrate was calculated by difference.

Determination of total phenolics and flavonoids compounds:

Total phenolic and flavonoids compounds contents of flour and crackers samples were determined calorimetrically using Folin-Ciocalteu reagent (as gallic acid) according to [14]. However, the total flavonoid compounds were determined (as quercetin) according to the method described by [15].

\section{Antioxidant activity of crackers formula:}

The antioxidant activities of flour and crackers samples were determined using the free radical, 2,2-diphenyl-1-picrylhydrazyl (DPPH) as a reagent and expressed as $\mu \mathrm{l} / \mathrm{mL}$ according to the method described by [16].

\section{Determination of minerals:}

The minerals sulfur $(\mathrm{S})$ iron $(\mathrm{Fe})$, magnesium $(\mathrm{Mg})$, potassium $(\mathrm{K})$, manganese $(\mathrm{Mn})$, zinc $(\mathrm{Zn})$, calcium $(\mathrm{Ca})$, phosphorous $(\mathrm{P})$ and sodium $(\mathrm{Na})$ were digested using microwave digestion system (Multiwave Go Plus) and determined by using microwave plasma Atomic Emission Spectroscopy (MP-AES) (model 4210, Agilent) made in Malaysia according to [17].

\section{Identification of phenolic and flavonoid components:}

A high-performance liquid chromatography system equipped with a variable wave length detector (Agilant, Germany) 1100, auto sampler, Quaternary pump degasser and column compartment. Analyses were performed on a C18 reverse phase (BDS $5 \mu \mathrm{m}$, Labio, Czech Republic) packed stainless-steel column $(4 \times 250$ $\mathrm{mm})$. To determine phenolic acids and flavonoids, samples were prepared according to the method described by [18]. The chromatographic conditions (mobile phase, gradient program, temperature of column) were similar to those described by [19]. All chromatograms were plotted at $280 \mathrm{~nm}$ to estimated phenolic acids and at $330 \mathrm{~nm}$ for flavonoids. All components were identified and quantified by comparison of peak areas with external standards.

\section{Mammalian cell lines:}

Potential Mammalian cell lines: HCT-116 cells (human colon cancer cell line), HepG-2 cells (human Hepatocellular carcinoma) and $\mathrm{CACO}_{2}$ cells (human intestinal cancer cell line) obtained from VACSERA Tissue Culture Unit were tested using the method of [20].

\section{Sensory evaluation:}

Sensory evaluation of crackers samples was evaluated for their sensory characteristics. The sensory attributes including color, odor, taste, crispy, and general appearance were evaluated by 15 trained members' panelist from Food Technology Research Institute [21].

\section{Statistical analysis:}

Statistical analysis Means \pm SD of the results are statistically analyzed using one-way analysis of variance (ANOVA), $\mathrm{p} \leq 0.05$ was used to indicate significance. Statistical software (Assistat Version 7.7, Brazil) was used for all statistical analyses according to [22]. 


\section{Results and Discussion}

Data in Table 2 showed the chemical composition of (wheat, Rice and cauliflower) flour and crackers samples. In raw samples the cauliflower recorded the highest value of moisture, ash, protein and fiber $(89.29 \%, 7.68 \%, 19.04 \%$ and $10.18 \%$ DW, respectively). Meanwhile, the rice recorded the lowest values for all chemical composition except the carbohydrate content recorded the highest value $(89.82 \% \mathrm{DW})$. These results were in the same line with [23] who stated that cauliflower protein, fiber, ash and carbohydrate content values were 24.31, 7.96, 10.87 and 51.66, respectively

On the other hands, the crackers sample showed no significant difference in moisture and ash, while in protein there was a significant difference between III, IV and I in wheat and cauliflower samples also, between V, VI, VII and VIII. The crackers samples) IV and VIII) recorded the highest values in moisture, ash, protein, fat and fiber. The data shows that increasing cauliflower percentage in crackers formula causes a parallel increasing in all determined chemical composition.

Also, Crackers recorded an increase in moisture content more than raw wheat and rice crackers up to 8.46 and 9.19 for (IV and VIII), respectively as showed in other studies using mixed flours, they mentioned that the increase of flour fiber content increase the moisture [24] [25].

The Brassica genus contains phenolic compounds, one of the bioactive compounds that have positive effects on human health. Total phenolic and flavonoid contents of wheat flour, rice flour, raw cauliflower and crackers samples revealed in "Table 3". From these results it could be noticed that raw cauliflower samples

Table 2. Chemical composition of raw cauliflower wheat flour, rice flour and crackers samples based on dry weight.

\begin{tabular}{cccccccc}
\hline & \multirow{2}{*}{ Samples } & \multicolumn{5}{c}{ On dry weight basis } \\
\cline { 3 - 8 } & F_WHE & Moisture & Ash & Protein & Fat & Fiber & Carbohydrate* \\
\hline & F_RIC & $12.48 \pm 0.83$ & $0.73 \pm 0.09$ & $12.78 \pm 1.09$ & $1.28 \pm 0.11$ & $0.82 \pm 0.30$ & $84.39 \pm 1.03$ \\
& F_CAUL & $10.57 \pm 0.92$ & $0.71 \pm 0.08$ & $8.15 \pm 0.765$ & $0.62 \pm 0.10$ & $0.70 \pm 0.05$ & $89.82 \pm 0.10$ \\
& No. of formula & $89.29 \pm 1.05$ & $7.68 \pm 0.08$ & $19.04 \pm 0.55$ & $2.33 \pm 0.22$ & $10.18 \pm 0.8$ & $60.77 \pm 0.94$ \\
I & CRA_100\% WHE & & & & & \\
II & CRA_(25\% CAUL + 75\% WHE) & $7.58^{\mathrm{b}}$ & $2.68^{\mathrm{d}}$ & $14.82^{\mathrm{b}}$ & $2.94^{\mathrm{abc}}$ & $9.58^{\mathrm{ab}}$ & $69.98^{\mathrm{d}}$ \\
III & CRA_(50\% CAUL + 50\% WHE) & $7.99^{\mathrm{b}}$ & $4.87^{\mathrm{c}}$ & $16.39^{\mathrm{a}}$ & $3.52^{\mathrm{ab}}$ & $9.89^{\mathrm{ab}}$ & $65.33^{\mathrm{e}}$ \\
IV & CRA_(75\% CAUL + 25\% WHE) & $8.46^{\mathrm{ab}}$ & $6.25^{\mathrm{a}}$ & $17.84^{\mathrm{a}}$ & $3.76^{\mathrm{a}}$ & $10.35^{\mathrm{a}}$ & $61.80^{\mathrm{f}}$ \\
V & CRA_100\% RIC & $7.70^{\mathrm{ab}}$ & $0.83^{\mathrm{e}}$ & $7.66^{\mathrm{e}}$ & $1.96^{\mathrm{c}}$. & $0.94^{\mathrm{f}}$ & $88.69^{\mathrm{a}}$ \\
VI & CRA_(25\% CAUL + 75\% RIC) & $7.54^{\mathrm{ab}}$ & $2.25^{\mathrm{d}}$ & $10.52^{\mathrm{d}}$ & $2.40^{\mathrm{c}}$ & $3.56^{\mathrm{e}}$ & $81.27^{\mathrm{b}}$ \\
VII & CRA_(50\% CAUL + 50\% RIC) & $8.58^{\mathrm{ab}}$ & $4.51^{\mathrm{c}}$ & $13.64^{\mathrm{bc}}$ & $2.98^{\mathrm{abc}}$ & $5.83^{\mathrm{d}}$ & $73.04^{\mathrm{c}}$ \\
VIII & CRA_(75\% CAUL + 25\% RIC) & $9.19^{\mathrm{a}}$ & $5.63^{\mathrm{b}}$ & $16.37^{\mathrm{a}}$ & $3.50^{\mathrm{ab}}$ & $7.74^{\mathrm{c}}$ & $66.76^{\mathrm{e}}$ \\
\hline
\end{tabular}

F_WHE: wheat flour $72 \%$ extraction; F_RIC: rice flour; F_CAUL: cauliflower; CRA: crackers; ${ }^{*}$ by difference. Values are mean of three replicates \pm SD, number in the same column followed by the same letter is not significantly different at 0.05 level. 
Table 3. Total phenolic and flavonoid contents of raw cauliflower, wheat flour, rice flour and crackers samples.

\begin{tabular}{|c|c|c|c|}
\hline & Samples & $\begin{array}{l}\text { Total phenolic content } \\
\left(\mathrm{mg} \text { Gallic acid } \mathrm{g}^{-1} \mathrm{dw}\right)\end{array}$ & $\begin{array}{l}\text { Total flavonoids content } \\
\left(\mathrm{mg} \text { quercetin } \mathrm{g}^{-1} \mathrm{dw}\right)\end{array}$ \\
\hline & F_WHE & $1.61 \pm 0.336$ & $0.95 \pm 0.025$ \\
\hline & F_RIC & $1.45 \pm 0.094$ & $0.67 \pm 0.041$ \\
\hline & F_CAUL & $8.48 \pm 0.200$ & $3.21 \pm 0.253$ \\
\hline & No. of formula & \multicolumn{2}{|c|}{ Products } \\
\hline I & CRA_100\% WHE & $0.75^{\mathrm{d}}$ & $0.35^{\mathrm{d}}$ \\
\hline II & CRA_(25\% CAUL + 75\% WHE $)$ & $2.68^{\mathrm{c}}$ & $1.54^{\mathrm{c}}$ \\
\hline III & CRA_( $50 \%$ CAUL + 50\% WHE) & $3.62^{\mathrm{b}}$ & $2.28^{\mathrm{b}}$ \\
\hline IV & CRA_(75\% CAUL + 25\% WHE) & $5.75^{\mathrm{a}}$ & $2.70^{\mathrm{a}}$ \\
\hline $\mathrm{V}$ & CRA_100\% RIC & $0.55^{\mathrm{d}}$ & $0.25^{\mathrm{d}}$ \\
\hline VI & CRA_(25\% CAUL + 75\% RIC) & $2.52^{\mathrm{c}}$ & $1.43^{\mathrm{c}}$ \\
\hline VII & CRA_(50\% CAUL + 50\% RIC) & $3.80^{\mathrm{b}}$ & $1.68^{\mathrm{c}}$ \\
\hline VIII & CRA_(75\% CAUL + 25\% RIC) & $5.49^{\mathrm{a}}$ & $2.54^{\mathrm{ab}}$ \\
\hline
\end{tabular}

F_WHE: wheat flour 72\% extraction; F_RIC: rice flour; F_CAUL: cauliflower; CRA: crackers. Values are mean of three replicates $\pm S D$, number in the same column followed by the same letter is not significantly different at 0.05 level.

were statistically higher in total phenol and flavonoid contents (8.48 and 3.21), respectively than wheat and rice flour samples $(1.61,0.95$ and $1.45,0.67)$, respectively. These results were higher than that of [26] they mentioned that total phenolic compounds for fresh cauliflower on dry weight was $4.61 \pm 0.08 \mathrm{mg} / \mathrm{g}$.

The difference between values refers to total phenols ability to vary between different cultivars cauliflower and different varieties used might also cause differences [27].

There was a high significate difference between I, II, III and IV also, between V, VI, VII and VIII samples for total phenolic and flavonoid contents at ( $\mathrm{p} \leq$ 0.05).

The highest values of phenols and flavonoids for cauliflower cracker samples) IV and VIII) have risen up to (5.75 and 5.49) respectively, followed by other samples according to cauliflower percentage in the formula. Moreover, the formulated crackers samples are lower than raw cauliflower but higher than wheat and rice in total phenolic and flavonoid compounds. For baked products, such as crackers it is possible the occurrence of the degradation and loss of phenolic compounds due to the heat and oxidation during the mixing and baking process [28] [29].

The results of antioxidants activity of wheat, rice flour, raw cauliflower, and formulated crackers samples showed in Figure 1. The figure illustrated that raw cauliflower samples showed the highest percentage of antioxidant activity (92.94\%) parallel with [26] who reported that antioxidant activity of cauliflower fresh (DPPH free radical) were $93.20 \%$ followed by crackers samples IV, III and 


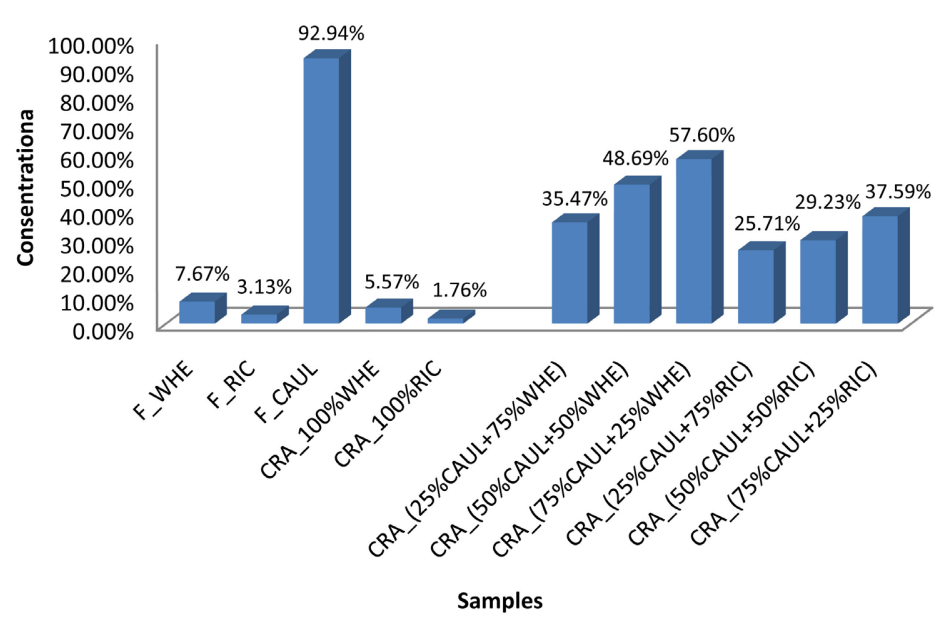

Figure 1. Antioxidant activity of raw cauliflower, wheat flour, rice flour and crackers samples DPPH (\% Inhibition).

VIII which have recorded (57.6\%, $48.69 \%$ and $37.59 \%)$. Meanwhile, the sample with $100 \%$ rice noted the lowest percentage of antioxidant activity (1.76\%).

From these results it could be revealed that the higher antioxidant activity of cauliflower due to its higher contents of phenolic and flavonoid compounds. Vice versa, the lowest antioxidant activity of rice sample could be due to the low contents of phenolic and flavonoid compounds. These results are in the same line with [30], who concluded that Brassica vegetables possess potent antioxidant properties attributed to the high levels phenolic compounds.

Several polyphenol compounds were identified in raw cauliflower, wheat flour, rice flour and crackers as showed in Table 4 and Table 5. The quantities of the compounds were expressed in $\mathrm{mg} / 100 \mathrm{~g}$. According to the presented results the highest value of flavonoids compounds was recorded to quercetin $(19.411 \mathrm{mg} /$ $100 \mathrm{gm})$ for cauliflower samples and the lowest value was recorded to kampferol $(0.005 \mathrm{mg} / 100 \mathrm{gm})$ for (VI) sample. Also, pyrogallol recorded the highest phenolic compound ratio 35.905 and $22.243 \mathrm{mg} / 100 \mathrm{gm}$ in cauliflower and wheat samples. Also, the percentage of the quercetin has increased up to 21.149 and $20.040 \mathrm{mg} / 100 \mathrm{gm}$ in (IV and VIII) samples respectively these results were in the same line with [31] who mention that baking and sautéing produced gain a 7\% $25 \%$ in quercetin concentration, while boiling produced decrease $18 \%$ in quercetin concentration. Furthermore, the flavonoids and phenols fractions for raw cauliflower, wheat and rice flour were higher than their mixtures crackers these results due to the high instability of polyphenols that cause numerous reactions in the course of food processing [28] [32] [33] [34] observed a reduction of phenolic acids levels of about $20 \%-30 \%$ in breads in comparison to start material-enriched flour.

Mineral contents of raw cauliflower, wheat and rice were presented in Table 6. From these results it could be noticed that the higher minerals content refers to markedly sulfur $(635.96 \mathrm{mg} / 100 \mathrm{~g})$ in raw cauliflower, while wheat and rice recoded 1.00 and $0.99 \mathrm{mg} / 100 \mathrm{~g}$, respectively. [35] pointed that cauliflowers were 
Table 4. Flavonoids fractions raw cauliflower, wheat flour, rice flour and crackers samples (mg/100g) by HPLC.

\begin{tabular}{|c|c|c|c|c|c|c|c|c|c|}
\hline \multicolumn{10}{|c|}{ Products } \\
\hline No. of formula & $\mathrm{X}$ & I & $\mathrm{V}$ & II & III & IV & VI & VII & VIII \\
\hline Sample & Cauliflower & $\begin{array}{c}\text { CRA_100\% } \\
\text { WHE }\end{array}$ & $\begin{array}{c}\text { CRA_100\% } \\
\text { rice }\end{array}$ & $\begin{array}{c}\text { CRA_(25\% } \\
\text { CAUL + } \\
75 \% \text { WHE })\end{array}$ & $\begin{array}{c}\text { CRA_(50\% } \\
\text { CAUL + } \\
50 \% \text { WHE })\end{array}$ & $\begin{array}{c}\text { CRA_(75\% } \\
\text { CAUL + } \\
25 \% \text { WHE })\end{array}$ & $\begin{array}{c}\text { CRA_(25\% } \\
\text { CAUL + } \\
75 \% \text { rice })\end{array}$ & $\begin{array}{c}\text { CRA_(50\% } \\
\text { CAUL + } \\
50 \% \text { ric })\end{array}$ & $\begin{array}{c}\text { CRA_(75\% } \\
\text { CAUL + } \\
25 \% \text { ric })\end{array}$ \\
\hline Naringin & 0.059 & - & - & - & 0.029 & 0.048 & - & - & - \\
\hline Rosmarinic & 0.341 & 1.329 & 0.309 & 1.356 & 0.999 & 0.499 & 0.247 & 0.163 & 0.112 \\
\hline Hesperdin & 0.502 & 2.741 & 1.927 & 2.097 & 1.880 & 1.275 & 1.495 & 1.472 & 1.3241 \\
\hline Rutin & 0.055 & 0.593 & 0.181 & 0.398 & 0.366 & 0.150 & 0.049 & 0.277 & 0.078 \\
\hline Quercetrin & 0.907 & - & 0.334 & - & - & - & - & - & - \\
\hline Naringen & 0.025 & 0.380 & 0.103 & 0.268 & 0.139 & 0.084 & 0.071 & 0.019 & 0.023 \\
\hline Quercetin & 19.411 & 0.231 & 0.059 & 6.753 & 12.017 & 21.149 & 4.039 & 10.930 & 20.040 \\
\hline $\begin{array}{c}\text { Kampferol } \\
\text { 3-2-p-coumaryl }\end{array}$ & 0.266 & 0.389 & 1.236 & 0.411 & 0.223 & 0.194 & 1.105 & 1.052 & 0.481 \\
\hline Kampferol & 2.518 & 0.103 & 0.125 & 0.009 & 0.041 & 0.077 & 0.005 & 0.039 & 0.189 \\
\hline Apignin & 0.022 & 0.287 & 0.089 & 0.065 & 0.054 & 0.134 & 0.047 & 0.029 & 0.025 \\
\hline
\end{tabular}

Table 5. Phenols fractions of raw cauliflower, wheat flour, rice flour and crackers samples (mg/100g) by HPLC.

\begin{tabular}{|c|c|c|c|c|c|c|c|c|c|}
\hline \multicolumn{10}{|c|}{ Products } \\
\hline No. of formula & $\mathrm{X}$ & I & $\mathbf{V}$ & II & III & IV & VI & VII & VIII \\
\hline Gallic acid & 0.577 & 0.168 & 0.059 & 0.075 & 0.061 & 0.260 & 0.029 & 0.037 & 0.094 \\
\hline Catechol & 0.072 & 0.111 & 0.014 & 0.108 & 0.062 & 0.038 & 0.004 & 0.006 & 0.023 \\
\hline $\begin{array}{l}\text { 4-Amino-benzoic } \\
\text { acid }\end{array}$ & 0.100 & 0.239 & 0.046 & 0.154 & 0.033 & - & 0.038 & 0.043 & 0.076 \\
\hline Catechein & 1.429 & 4.301 & 0.268 & 3.352 & 1.106 & 0.586 & 0.884 & 0.935 & 1.219 \\
\hline Benzoic acid & 1.299 & 1.075 & - & 0.072 & 0.349 & 0.667 & - & - & 0.528 \\
\hline P-OH-benzoic acid & 0.967 & 0.616 & 0.129 & 0.179 & 0.445 & 0.839 & 0.095 & 0.251 & 0.546 \\
\hline Vanillic acid & 0.199 & 1.184 & 0.330 & 1.050 & 0.389 & 0.354 & 0.213 & 0.174 & 0.117 \\
\hline Caffeic acid & 0.339 & 0.365 & 0.072 & 0.183 & 0.108 & - & 0.097 & 0.164 & 0.273 \\
\hline caffeine & 0.801 & 0.670 & 0.230 & 0.101 & 0.124 & 0.537 & 0.064 & 0.075 & 0.223 \\
\hline Ferulic acid & 0.318 & 1.059 & 0.283 & 0.920 & 0.487 & 0.381 & 0.194 & 0.273 & 0.348 \\
\hline Salycilic acid & 0.954 & 4.700 & 1.113 & 1.066 & 0.597 & 0.254 & 1.292 & 1.282 & 0.794 \\
\hline Ellagic acid & 1.450 & 0.662 & 0.489 & 0.307 & 0.401 & 0.551 & - & 0.247 & 0.259 \\
\hline coumarin & 0.573 & 2.234 & 1.061 & 1.688 & 1.486 & 1.332 & 0.969 & 0.845 & - \\
\hline
\end{tabular}


Table 6. Minerals contents of raw cauliflower, wheat flour, rice flour $(\mathrm{mg} / 100 \mathrm{~g})$ on dry weight basis.

\begin{tabular}{cccc}
\hline Sample & $100 \%$ CAUL & $100 \%$ Wheat flour & $100 \%$ Rice \\
\hline $\mathrm{S}$ & $635.96 \pm 1.05$ & $1.00 \pm 0.01$ & $0.99 \pm 0.01$ \\
$\mathrm{Zn}$ & $3.75 \pm 0.71$ & $0.33 \pm 0.17$ & $0.210 \pm 0.28$ \\
$\mathrm{~K}$ & $319.37 \pm 0.57$ & $133.11 \pm 2.71$ & $160.0 \pm 0.28$ \\
$\mathrm{Mn}$ & $2.81 \pm 0.275$ & $0.280 \pm 0.10$ & $0.215 \pm 0.03$ \\
$\mathrm{P}$ & $386.02 \pm 1.87$ & $158.00 \pm 1.73$ & $160.0 \pm 0.28$ \\
$\mathrm{Fe}$ & $7.55 \pm 0.264$ & $1.45 \pm 0.02$ & $1.42 \pm 0.01$ \\
$\mathrm{Mg}$ & $168.64 \pm 1.10$ & $149 \pm 7.00$ & $125.50 \pm 0.28$ \\
$\mathrm{Ca}$ & $136.42 \pm 1.36$ & $54.00 \pm 1.00$ & $28.85 \pm 0.04$ \\
$\mathrm{Na}$ & $187.57 \pm 0.57$ & $108.01 \pm 1.50$ & $71.1 \pm 0.38$ \\
\hline
\end{tabular}

Values are mean of three replicates \pm SD.

characterized by higher sulfur content in a results of minerals contents. On the other hand, sodium, phosphorous and potassium are 487.57, 386.02 and 319.37 $\mathrm{mg} / 100 \mathrm{~g}$. The potassium content of Brassica oleracae var. was in the range of 221 $-712 \mathrm{mg} / 100 \mathrm{~g}$ [36]. From the same table it can be also seen that the highest content in other minerals $(\mathrm{Zn}, \mathrm{Mn}, \mathrm{Fe}$ and $\mathrm{Mg}$ ) were higher than wheat and rice. "Table 7 and Table 8" showed that the highest sulfur content and other minerals were found in $(75 \%$ cauliflower) followed by $(50 \%, 25 \%)$ cracker samples. These finding indicate that the increasing of cauliflower percentage increases the minerals contents specially the sulfur levels. [37] reported that when $\mathrm{Na} / \mathrm{K}$ is ratio less than one it has a great importance in the human body for the control of high blood pressure.

The in vitro Anticancer activity of cauliflower $(\mu \mathrm{g} / \mathrm{mL})$

Hep G2 (Human hepatocellular carcinoma), HCT116 (colon cancer) and Caco-2 (intestinal carcinoma cell lines as a model of the intestinal epithelial barrier). Cell lines were examined using Mammalian cell lines "Table 9". The increase in the growth inhibition was recorded in dose-dependent manner. Cell Inhibitory percentage increased to $87.04 \%, 83.66 \%$ and $74.28 \%$ in Hep G2, HCT116, and Caco-2 cell lines, respectively at concentration of $500 \mu \mathrm{g} / \mathrm{mL}$. These results indicated that the maximum inhibiting effect of cauliflower was found to be against Human hepatocellular carcinoma followed by colon cancer cell lines. This detected inhibition effect of cauliflower may refer to the phenolic compounds content and its antioxidant effects. Evidences have accumulated to suggest that flavonoids have potential role to suppress tumor cell proliferation and may effectively work as chemo-preventive agents against carcinogenesis in humans [38]. Several studies have indicated high cytotoxic and anticancer activity of flavonoids [39] [40] [41] [42]. Phytonutrients, such as phenols flavonoids were statistically higher values indicating that cauliflower is a good source of those phytochemicals. Similarly, the highest levels of total phenol, total flavonoids and antioxidant activity were 
Table 7. Minerals contents of raw cauliflower and wheat flour crackers samples ( $\mathrm{mg} / 100 \mathrm{~g})$ on dry weight basis.

\begin{tabular}{ccccc}
\hline \multicolumn{5}{c}{ Products } \\
\hline $\begin{array}{c}\text { No. } \\
\text { of formula }\end{array}$ & I & II & III & IV \\
\hline Sample & $\begin{array}{c}\text { CRA_100\% } \\
\text { WHE }\end{array}$ & CAUL + 75\% WHE) & CAUL + $50 \%$ WHE) & CAUL + 25\% WHE) \\
\hline S & $1.70^{\mathrm{d}}$ & $169.49^{\mathrm{c}}$ & $216.18^{\mathrm{b}}$ & $288.90^{\mathrm{a}}$ \\
$\mathrm{Zn}$ & $1.03^{\mathrm{c}}$ & $1.08^{\mathrm{b}}$ & $1.13^{\mathrm{a}}$ & $1.14^{\mathrm{a}}$ \\
$\mathrm{K}$ & $207.51^{\mathrm{d}}$ & $296.16^{\mathrm{c}}$ & $406.64^{\mathrm{b}}$ & $566.18^{\mathrm{a}}$ \\
$\mathrm{Mn}$ & $1.40^{\mathrm{d}}$ & $1.98^{\mathrm{c}}$ & $2.25^{\mathrm{b}}$ & $2.46^{\mathrm{a}}$ \\
$\mathrm{P}$ & $146.69^{\mathrm{d}}$ & $238.66^{\mathrm{c}}$ & $374.87^{\mathrm{b}}$ & $463.35^{\mathrm{a}}$ \\
$\mathrm{Fe}$ & $1.62^{\mathrm{c}}$ & $3.37^{\mathrm{b}}$ & $3.57^{\mathrm{b}}$ & $4.46^{\mathrm{a}}$ \\
$\mathrm{Mg}$ & $128.29^{\mathrm{d}}$ & $249.00^{\mathrm{c}}$ & $291.92^{\mathrm{b}}$ & $360.59^{\mathrm{a}}$ \\
$\mathrm{Ca}$ & $51.09^{\mathrm{d}}$ & $88.50^{\mathrm{c}}$ & $171.23^{\mathrm{b}}$ & $224.66^{\mathrm{a}}$ \\
$\mathrm{Na}$ & $94.09^{\mathrm{d}}$ & $108.48^{\mathrm{c}}$ & $142.89^{\mathrm{b}}$ & $186.96^{\mathrm{a}}$ \\
$\mathrm{Na} / \mathrm{K}$ & 0.45 & 0.37 & 0.35 & 0.33 \\
\hline
\end{tabular}

F_WHE: wheat flour 72\% extraction; F_CAUL: cauliflower; CRA: crackers. Values are mean of three replicates $\pm \mathrm{SD}$, number in the same row followed by the same letter is not significantly different at 0.05 level.

Table 8. Minerals contents of raw cauliflower and rice flour crackers samples $(\mathrm{mg} / 100 \mathrm{~g})$ on dry weight basis.

\begin{tabular}{ccccc}
\hline \multicolumn{5}{c}{ Products } \\
$\begin{array}{c}\text { No. } \\
\text { of formula }\end{array}$ & V & VI & VII & VIII \\
\hline Sample & $\begin{array}{c}\text { CRA_100\% } \\
\text { RIC }\end{array}$ & $\begin{array}{c}\text { CRA_(25\% } \\
\text { CAUL + 75\% RIC) }\end{array}$ & $\begin{array}{c}\text { CRA_(50\% } \\
\text { CAUL + 50\% RIC) }\end{array}$ & $\begin{array}{c}\text { CRA_(75\% } \\
\text { CAUL + 25\% RIC) }\end{array}$ \\
\hline S & $1.29^{\mathrm{d}}$ & $114.38^{\mathrm{c}}$ & $196.65^{\mathrm{b}}$ & $237.42^{\mathrm{a}}$ \\
$\mathrm{Zn}$ & $0.41^{\mathrm{c}}$ & $1.24^{\mathrm{b}}$ & $1.52^{\mathrm{a}}$ & $1.53^{\mathrm{a}}$ \\
$\mathrm{K}$ & $193.38^{\mathrm{d}}$ & $277.97^{\mathrm{c}}$ & $294.73^{\mathrm{b}}$ & $305.45^{\mathrm{a}}$ \\
$\mathrm{Mn}$ & $0.30^{\mathrm{d}}$ & $0.97^{\mathrm{c}}$ & $1.14^{\mathrm{b}}$ & $1.31^{\mathrm{a}}$ \\
$\mathrm{P}$ & $166.60^{\mathrm{d}}$ & $222.79^{\mathrm{c}}$ & $268.38^{\mathrm{b}}$ & $343.88^{\mathrm{a}}$ \\
$\mathrm{Fe}$ & $1.38^{\mathrm{d}}$ & $3.29^{\mathrm{c}}$ & $4.21^{\mathrm{b}}$ & $4.93^{\mathrm{a}}$ \\
$\mathrm{Mg}$ & $115.02^{\mathrm{d}}$ & $129.71^{\mathrm{c}}$ & $135.72^{\mathrm{b}}$ & $164.93^{\mathrm{a}}$ \\
$\mathrm{Ca}$ & $38.03^{\mathrm{d}}$ & $77.40^{\mathrm{c}}$ & $90.22^{\mathrm{b}}$ & $105.16^{\mathrm{a}}$ \\
$\mathrm{Na}$ & $93.03^{\mathrm{d}}$ & $100.56^{\mathrm{c}}$ & $133.55^{\mathrm{b}}$ & $179.44^{\mathrm{a}}$ \\
$\mathrm{Na} / \mathrm{K}$ & 0.48 & 0.36 & 0.45 & 0.58 \\
\hline
\end{tabular}

F_RIC: rice flour; F_CAUL: cauliflower; CRA: crackers. Values are mean of three replicates \pm SD, number in the same row followed by the same letter is not significantly different at 0.05 level. 
Table 9. Anticancer activity of raw cauliflower $(\mu \mathrm{g} / \mathrm{mL})$.

\begin{tabular}{|c|c|c|c|}
\hline \multirow[b]{2}{*}{$\begin{array}{l}\text { Concentration } \\
(\mu \mathrm{g} / \mathrm{mL})\end{array}$} & \multicolumn{3}{|c|}{ Inhibitory \% } \\
\hline & $\begin{array}{c}\text { Hep G2 } \\
\text { (Human } \\
\text { hepatocellular carcinoma) }\end{array}$ & $\begin{array}{c}\text { HCT116 } \\
\text { colon } \\
\text { carcinoma cells }\end{array}$ & $\begin{array}{c}\text { Caco-2 } \\
\text { intestinal } \\
\text { carcinoma cells }\end{array}$ \\
\hline 500 & 87.04 & 83.66 & 74.29 \\
\hline 250 & 70.53 & 68.08 & 62.82 \\
\hline 125 & 31.98 & 37.63 & 25.37 \\
\hline 62.5 & 12.46 & 10.6 & 9.02 \\
\hline 31.25 & 1.39 & 2.12 & 0.8 \\
\hline 15.6 & 0 & 0 & 0 \\
\hline 7.8 & 0 & 0 & 0 \\
\hline 3.9 & 0 & 0 & 0 \\
\hline 0 & 0 & 0 & 0 \\
\hline IC50 & $183.4 \pm 6.8$ & $175.8 \pm 7.1$ & $207.2 \pm 8.5$ \\
\hline
\end{tabular}

observed in the cauliflower cultivars [43]. Samples with IC50 value between 125 and $5000 \mu \mathrm{g} / \mathrm{mL}$ was considered to have moderate potential to be developed into a cancer therapeutic agent [44]. In this study, cauliflower may be considered as moderate potential for Human hepatocellular carcinoma, colon cancer and intestinal epithelial barrier treatment, materials, $(183.4 \pm 6.8,175.8 \pm 7.1$ and $207.2 \pm$ $8.5 \mu \mathrm{g} / \mathrm{mL}$ ). The moderate potential protective effect against risk of cancer could be referred to Sulfur which considered as a commonly used in Asia as an herbal medicine to treat inflammation and cancer, and potent chemo-preventive effects have been demonstrated in various in vivo and in vitro models for sulfur-containing compounds found in naturally occurring products [45].

Sensory evaluation of wheat and rice crackers which were replaced with cauliflower crackers were shown in Table 10. From the obtained results it was observed that increase of cauliflower caused no significant differences on general appearance between control and other samples (Whether wheat or rice crackers). It was noticed that there were significant differences in the taste property, the highest degree of acceptance of the taste was obtained to crackers samples which were replaced with cauliflower more than the control, may be the addition of cauliflower and anise improved the taste. On the other hand, it was noticed that the preference of crispy was decreased as the cauliflower percentage increase compared to the control samples, crispiness may be referred to the increasing of moisture contents. Crispness is a textural attribute which is an important indicator of the quality of dry crisp products. This work includes an overview of structural properties necessary for a product to be considered crisp as well as information related to moisture. [46]. Gelatinized starch and pentosans are other network forming flour polymers capable of forming highly water-holding entanglement gels in a cookie or cracker dough [47]. Also, it was noticed that there 
Table 10. Sensory evaluation of crackers samples.

\begin{tabular}{ccccccc}
\hline $\begin{array}{c}\text { No. of } \\
\text { formula }\end{array}$ & Blends & $\begin{array}{c}\text { General } \\
\text { appearance }\end{array}$ & Odor & Taste & Crispy & Color \\
\hline \multicolumn{2}{c}{ Wheat crackers } \\
I & CRA_100\% WHE & $19.41^{\mathrm{a}}$ & $19.50^{\mathrm{a}}$ & $17.82^{\mathrm{b}}$ & $19.51^{\mathrm{a}}$ & $19.50^{\mathrm{a}}$ \\
II & CRA_(25\% CAUL + 75\% WHE) & $19.43^{\mathrm{a}}$ & $19.00^{\mathrm{a}}$ & $18.20^{\mathrm{a}}$ & $18.80^{\mathrm{b}}$ & $19.52^{\mathrm{a}}$ \\
III & CRA_(50\% CAUL + 50\% WHE) & $19.50^{\mathrm{a}}$ & $18.70^{\mathrm{a}}$ & $18.83^{\mathrm{a}}$ & $18.42^{\mathrm{b}}$ & $19.51^{\mathrm{a}}$ \\
IV & CRA_(75\% CAUL + 25\% WHE) & $19.54^{\mathrm{a}}$ & $17.20^{\mathrm{b}}$ & $18.71^{\mathrm{a}}$ & $18.13^{\mathrm{b}}$ & $19.50^{\mathrm{a}}$ \\
\hline & & Rice crackers & & & & \\
V & CRA_100\% RIC & $19.62^{\mathrm{a}}$ & $19.71^{\mathrm{a}}$ & $17.72^{\mathrm{c}}$ & $19.80^{\mathrm{a}}$ & $20.00^{\mathrm{a}}$ \\
VI & CRA_(25\% CAUL + 75\% RIC) & $19.60^{\mathrm{a}}$ & $19.13^{\mathrm{a}}$ & $18.30^{\mathrm{b}}$ & $19.20^{\mathrm{ab}}$ & $19.76^{\mathrm{a}}$ \\
VII & CRA_(50\% CAUL + 50\% RIC) & $19.61^{\mathrm{a}}$ & $18.22^{\mathrm{b}}$ & $19.51^{\mathrm{ab}}$ & $18.51 \mathrm{~b}^{\mathrm{c}}$ & $19.82^{\mathrm{a}}$ \\
VIII & CRA_(75\% CAUL + 25\% RIC) & $19.71^{\mathrm{a}}$ & $17.31^{\mathrm{b}}$ & $19.63^{\mathrm{a}}$ & $18.11^{\mathrm{c}}$ & $19.91^{\mathrm{a}}$ \\
\hline
\end{tabular}

F_WHE: Wheat flour 72\% extraction; F_RIC: Rice flour; F_CAUL: Cauliflower; CRA: Crackers. Values are mean of three replicates \pm SD, number in the same column followed by the same letter is not significantly different at 0.05 level.

were no significant differences in color between the control of wheat, rice sample and crackers with cauliflower replacement. The results also showed that there were significant differences with odor between the wheat, rice control sample and the crackers with cauliflower replacements, Results highlighted that the samples including the control in terms of overall quality, the crackers with cauliflower were most appreciated, since this sample showed the higher scores for sensory attributes evaluated.

\section{Conclusion}

From these results, it could be concluded that the cauliflower can be used to replace $25 \%$ up to $75 \%$ of wheat and rice flour in crackers making without adverse effect on the consumer acceptability of the crackers. Also, the addition of cauliflower flour increased nutrition value, antioxidant activity, minerals and anti-carcinogenic components contents as compared with wheat and rice crackers. Also, these results indicate that cauliflower flours can be effectively incorporated into gluten-free crackers to improve the functional properties and sensory quality.

\section{Conflicts of Interest}

The authors declare no conflicts of interest regarding the publication of this paper.

\section{References}

[1] Manju, K. and Meera, D. (2020) Scheduling of Irrigation in Cauliflower (Brassica oleracea var. botrytis L.) under Mid Hill Conditions of Himachal Pradesh. International Journal of Current Microbiology and Applied Sciences, 9, 765-773. https://doi.org/10.20546/ijcmas.2020.906.098 
[2] Ribeiro, T.C., Abreu, J.P., Freitas, M.C.J., Pumar, M. and Teodoro, A.J. (2015) Substitution of Wheat Flour with Cauliflower Flour in Bakery Products: Effects on Chemical, Physical, Antioxidant Properties and Sensory Analyses. International Food Research Journal, 22, 532-538.

[3] Kirsh, V.A, Peters, U., Mayne, S.T., Subar, A.F., Chatterjee, N., Johnson, C.C. and Hayes, R.B. (2007) Prostate, Lung, Colorectal and Ovarian Cancer Screening Trial. Prospective Study of Fruit and Vegetable Intake and Risk of Prostate Cancer. Journal of the National Cancer Institute, 99, 1200-1209.

https://doi.org/10.1093/jnci/djm065

[4] Abdull, R.A. and Noor, N.M. (2013) Cruciferous Vegetables: Dietary Phytochemicals for Cancer Prevention. Asian Pacific Journal Cancer Prevention, 14, 1565-1570. https://doi.org/10.7314/APJCP.2013.14.3.1565

[5] Turati, F., Rossi, M., Pelucchi, C., Levi, F. and La Vecchia, C. (2015) Fruit and Vegetables and Cancer Risk: A Review of Southern European Studies. British Journal of Nutrition, 113, S102-S110. https://doi.org/10.1017/S0007114515000148

[6] Cerella, C., Dicato, M., Jacob, C. and Diederich, M. (2011) Chemical Properties and Mechanisms Determining the Anti-Cancer Action of Garlic-Derived Organic Sulfur Compounds. Anti-Cancer Agents in Medicinal Chemistry (Formerly Current Medicinal Chemistry-Anti-Cancer Agents), 11, 267-271.

https://doi.org/10.2174/187152011795347522

[7] Cartea, M.E., Francisco, M., Soengas, P. and Velasco, P. (2011) Phenolic Compounds in Brassica Vegetables. Molecules, 16, 251-280. https://doi.org/10.3390/molecules16010251

[8] Salehi, B., Azzini, E., Zucca, P., Varoni, M. E., Kumar, N. A., Dini, L., Sharifi-Rad, J., et al. (2020) Plant-Derived Bioactives and Oxidative Stress-Related Disorders: A Key Trend towards Healthy Aging and Longevity Promotion. Applied Sciences, 10, Article No. 947. https://doi.org/10.3390/app10030947

[9] Podsedek, A. (2007) Natural Antioxidants and Antioxidant Capacity of Brassica Vegetables: A Review. LWT-Food Science and Technology, 40, 1-11. https://doi.org/10.1016/j.lwt.2005.07.023

[10] Jnawali, P., Kumar, V. and Tanwar, B. (2016) Celiac Disease: Overview and Considerations for Development of Gluten-Free Foods. Food Science and Human Wellness, 5, 169-176. https://doi.org/10.1016/j.fshw.2016.09.003

[11] Mihiranie, S., Jayasundera, M. and Perera, N. (2021) Development of Snack Crackers Incorporated with Defatted Coconut Flour. Journal of Microbiology, Biotechnology and Food Sciences, 7, 153-159.

https://doi.org/10.15414/jmbfs.2017.7.2.153-159

[12] Sathe, S.K., Tamhane, D.V. and Salunkhe, D.K. (1981) Studies in Saling Crackers (Khara Biscuits): Portion Enrichment and Storge Stability. Cereal Food World, 26, 407-409.

[13] Association of Official Analytical Chemists (2005) Official Methods of Analysis. 18th Edition, Association of Official Analytical Chemists, Washington DC.

[14] Singleton, V., Orthofer, R. and Lamuela-Raventos, R.M. (1999) Analysis of Total Phenols and Other Oxidation Substrates and Antioxidations by Mean of Folin-Ciocalteu Reagent. Methods in Enzymology, 299, 152-178.

https://doi.org/10.1016/S0076-6879(99)99017-1

[15] Marinova, D., Ribarova, F. and Atanassova, M. (2005) Total Phenolics and Total Flavonoids in Bulgarian Fruits and Vegetables. Journal of the University of Chemical Technology and Metallurgy, 40, 255-260. 
[16] Cuendet, M., Hostettmann, K., Potterat, O. and Dyatmiko, W. (1997) Iridoid Glucosides with Free Radical Scavenging Properties from Fagraea blumei. Helvetica Chimica Acta, 80, 1144-1152. https://doi.org/10.1002/hlca.19970800411

[17] Association of Official Analytical Chemists (2019) AOAC Official Method 2015.01 Heavy Metals in Food. Inductively Coupled Plasma-Mass Spectrometry First Action 2015. Association of Official Analytical Chemists, Washington DC.

[18] Jakopic, J., Veberic, R. and Stampar, F. (2009) Extraction of Phenolic Compounds from Green Walnut Fruits in Different Solvents. Acta agriculturae Slovenica, 93, 11-15. https://doi.org/10.2478/v10014-009-0002-4

[19] Schieber, A., Keller, P. and Carle, R. (2001) Determination of Phenolic Acids and flavonoids of Apple and Pear by High-Performance Liquid Chromatography. Journal of Chromatography $A, 910,265-273$. https://doi.org/10.1016/S0021-9673(00)01217-6

[20] Gomha, S.M., Riyadh, S.M., Mahmmoud, E.A. and Elaasser, M.M. (2015) Synthesis and Anticancer Activities of Thiazoles, 1,3-Thiazines, and Thiazolidine Using Chitosan-Grafted-Poly(Vinylpyridine) as Basic Catalyst. Heterocycles, 91, 1227-1243. https://doi.org/10.3987/COM-15-13210

[21] Stone, H. and Sidel, J. (2004) Sensory Evaluation Practices, 3rd Edition, Academic Press, London. https://doi.org/10.1016/B978-0-12-672690-9.X5000-8

[22] Silva, F.A. and Azevedo, C.A. (2009) Principal Components Analysis in the Software Assistat Statistical Assistance. 7 th World Congress on Computers in Agriculture Conference Proceedings, Reno, 22-24 June 2009, 711P0409e.

[23] Hegazy, A.E. and Ammar, M.S. (2019) Utilization of Cauliflower (Brassica oleracea L. ssp. botrytis) Stem Flour in Improving Balady Bread Quality. Al-Azhar Journal of Agricultural Research, 44, 112-118.

https://dx.doi.org/10.21608/ajar.2019.59703

[24] Mauro, A., Silva, V. and Freitas, M. (2010) Caracterização física, química e sensorial de cookies confeccionados com Farinha de Talo de Couve (CSF) e Farinha de Talo de Espinafre (FTE) ricas em fibra alimentar. Food Science and Technology, 30, 719-728. https://doi.org/10.1590/S0101-20612010000300024

[25] Perez, P. and Germani, R. (2007) Elaboração de biscoito tipo salgado com alto teor de fibra alimentar, utilizando farinha de berinjela (Solanum melogena, L.). Food Science and Technology, 27, 186-192. https://doi.org/10.1590/S0101-20612007000100033

[26] Alloush, S.A. and Salem, A.A (2014) Effect of Cooking on Bioactive Compounds of Broccoli and Cauliflower. Advances in Food Science, 36, 2-10.

[27] Singh, J., Upadhyay, A., Prasad, K., Bahadur, A. and Rai, M. (2007) Variability of Carotenes, Vitamin C, E and Phenolics in Brassica Vegetables. Journal of Food Composition and Analysis, 20, 106-112. https://doi.org/10.1016/j.jfca.2006.08.002

[28] Holtekjølen, A.K., Bævre, A.B., Rødbotten, M., Berg, H. and Knutsen, S.H. (2008) Antioxidant Properties and Sensory Profiles of Bread Containing Barley Flour. Food chemistry, 110, 414-421. https://doi.org/10.1016/j.foodchem.2008.02.054

[29] Saccotelli, M.A., Spinelli, S., Conte, A. and Del Nobile, M.A.(2018) Gluten-Free Bread Enriched with Vegetable Flours. Food and Nutrition Sciences, 9, 356-368. https://doi.org/10.4236/fns.2018.94028 http://www.scirp.org/journal/fns

[30] Xiao, Z., Rausch, S.R., Luo, Y., Sun, J., Yu, L., Wang, Q. and Stommel, J.R. (2019) Microgreens of Brassicaceae: Genetic Diversity of Phytochemical Concentrations and Antioxidant Capacity. LWT-Food Science and Technology, 101, 731-737. 
https://doi.org/10.1016/j.lwt.2018.10.076

[31] Lombard, K.A., Geoffriau, E. and Peffley, E. (2002) Flavonoid Quantification in Onion by Spectrophotometric and High Performance Liquid Chromatography Analysis. HortScience, 37, 682-685. https://doi.org/10.21273/HORTSCI.37.4.682

[32] Cheynier, V. (2005) Polyphenols in Food Are More Complex than Often Thought. American Journal of Clinical Nutrition, 81, 223S-229S. https://doi.org/10.1093/ajcn/81.1.223S

[33] Chlopicka, J., Pasko P., Gorinstein, S., Jedryas, A. and Zagrodzki, P. (2012) Total Phenolic and Total Flavonoid Content, Antioxidant Activity and Sensory Evaluation of Pseudocereal Breads. LWT-Food Science and Technology, 46, 548-555. https://doi.org/10.1016/j.lwt.2011.11.009

[34] Han, H.M. and Koh, B.K. (2011) Antioxidant Activity of Hard Wheat Flour, Dough and Bread Prepared Using Various Processes with the Addition of Different Phenolic Acids. Journal of the Science of Food and Agriculture, 91, 604-608. https://doi.org/10.1002/jsfa.4188

[35] Ahmed, F.A. and Ali, R.M. (2013) Bioactivity Compounds and Antioxidant Activity of Fresh and Processed White Cauliflower. BioMed Research International, 2013, Article ID: 367819. https://doi.org/10.1155/2013/367819

[36] Tirasoglu, E., Cevik, U., Ertugral, B., Apaydin, G., Baltas, H. and Ertugrul, M. (2005) Determination of Trace Elements in Cole (Brassica oleraceae var. acephale) at Trabzon Region in Turkey. Journal of Quantum Spectroscopy, 94, 181-187.

https://doi.org/10.1016/j.jqsrt.2004.09.008

[37] Aremu, M., Olaofe, O. and Akintayo, T. (2006) A Comparative Study on the Chemical and Amino Acid Composition of Some Nigerian Underutilized Legume Flours. Pakistan Journal of Nutrition, 5, 34-38.

[38] Kobayashi, T., Nakata, T. and Kuzumaki, T. (2002) Effect of Flavonoids on Cell Cycle Progression in Prostate Cancer Cells. Cancer Letters, 176, 17-23. https://doi.org/10.1016/S0304-3835(01)00738-8

[39] Canadanovic-Brunet, J., Cetkovic, G., Dilas, S., Tumbas, V., Bogdanovic, G., Mandic, A., Markov, S., Cvetkovic, D. and Canadanovic, V. (2008) Radical Scavenging, Antibacterial, and Antiproliferative Activities of Melissa officinalis L. Extracts. Journal of Medicinal Food, 11, 133-143. https://doi.org/10.1089/jmf.2007.580

[40] Chang, H., Xie, Q., Zhang, Q., Peng, X., Zhu, J. and Mi, M. (2013) Flavonoids, Flavonoid Subclasses and Breast Cancer Risk: A Meta-Analysis of Epidemiologic Studies. PLoS ONE, 8, e54318. https://doi.org/10.1371/journal.pone.0054318

[41] Liu, Y., Zhan, J., Liu, X., Wang, Y., Ji, J. and He, Q. (2014) Dietary Flavonoids Intake and Risk of Type 2 Diabetes: A Meta-Analysis of Prospective Cohort Studies. Clinical Nutrition, 33, 59-63. https://doi.org/10.1016/j.clnu.2013.03.011

[42] Guercio, V., Turati, F., La Vecchia, C., Galeone, C. and Tavani, A. (2016) Allium Vegetables and Upper Aerodigestive Tract Cancers: A Metaanalysis of Observational Studies. Molecular Nutrition \& Food Research, 60, 212-222. https://doi.org/10.1002/mnfr.201500587

[43] Shiva, R.B. and Jung-Ho, K. (2015) Chemical Composition and Antioxidant Activity in Different Tissues of Brassica Vegetables. Molecules, 20, 1228-1243. https://doi.org/10.3390/molecules20011228

[44] Manosroi, J., Dhumtanom, P. and Manosroi A. (2006) Anti-Proliferative Activity of Essential Oil Extracted from Thai Medicinal Plants on KB and P388 Cell Lines. Cancer Letters, 235, 114-120. https://doi.org/10.1016/j.canlet.2005.04.021 
[45] Lee, J., Lee, H.J., Park, J.D., Lee, S.K., Lee, S.I., Lim, H.D. and Kim, E.C. (2008) Anti-Cancer Activity of Highly Purified Sulfur in Immortalized and Malignant Human Oral Keratinocytes. Toxicology in Vitro, 22, 87-95.

https://doi.org/10.1016/j.tiv.2007.08.016

[46] Kilcast, D. (Ed.) (2013) Instrumental Assessment of Food Sensory Quality: A Practical Guide. Woodhead Publishing, Cambrige.

https://doi.org/10.1533/9780857098856

[47] Levine, H. and Faubion, J.M. (1990) Dough Rheology and Backed Product Texture. AVI, Van Nostrand Reinhold, New York. 